\title{
CHARACTER BUILDING MAHASISWA MELALUI MKU PENDIDIKAN JASMANI
}

\author{
Alvi Meyviliano, Surdiniaty Ugelta \\ Program Studi Ilmu Keolahragaan \\ Departemen Pendidikan Kesehatan dan Rekreasi \\ Fakultas Pendidikan Olahraga dan Kesehatan \\ Universitas Pendidikan Indonesia, Jl. Dr. Setiabudhi No. 229 Bandung \\ Email : alvimyvlno@yahoo.com
}

\begin{abstract}
Abstrak
Tujuan penelitian ini yaitu untuk mengetahui gambaran karakter mahasiswa yang mengikuti dan tidak mengikuti perkuliahan pendidikan jasmani dan olahraga. Metode penelitian yang digunakan yaitu metode deskriptif komparatif. Sampel penelitian yang digunakan sebanyak 27 orang dari mahasiswa dan mahasiswi IEKI angkatan 2016. Dengan menggunakan teknik intact group comparison, sampel dibagi dua kelompok. Instrumen penelitian yang di gunakan yaitu berupa angket atau kuesioner mengenai kepercayaan (trustworthinees), tanggung jawab (responsibillity), rasa hormat (respect), rasa adil (fairness), peduli (caring) dan sosial (citizenship). Berdasarkan hasil pengolahan data dan analisis data menggunakan Independent Sample T Test, nilai yang di peroleh untuk mahasiswa yang mengikuti perkuliahan pendidikan jasmani olahraga cukup tinggi, maka dari itu penulis mengambil kesimpulan sebagai berikut: terdapat perbedaan karakter mahasiswa yang dan yang tidak mengikuti mata kuliah umum pendidikan jasmani olahraga.
\end{abstract}

Kata Kunci : Character Building dan MKU Pendidikan Jasmani Olahraga

\section{PENDAHULUAN}

Pendidikan jasmani dan olahraga yang ada di dalam kurikulum Universitas Pendidikan Indonesia (UPI) menjadi salah satu pembelajaran yang wajib diajarkan kepada mahasiswa/i. Pendidikan jasmani dan olahraga merupakan salah satu mata kuliah wajib yang diikuti oleh mahasiswa diperguruan tinggi lainnya. Pendidikan jasmani dan olahraga (PENJASOR) masuk kedalam Mata Kuliah Umum (MKU) dalam kurikulum di UPI. Tujuan mata kuliah umum di lingkungan UPI khususnya adalah untuk mengembangkan aspek kepribadian mahasiswa sebagai individu dan wargamasyarakat.(http://www.upi.edu/akademi k/kurikulum) Program pendidikan jasmani yang diterapkan kedalam MKU di UPI memiliki tujuan yang sangat penting yaitu mendidik melalui aktivitas olahraga dan juga sebagai sarana untuk mengembangakan diri para mahasiswa dan mahasiswi dalam berolahraga sesuai minatnya masing-masing. Peranan yang sangat penting dalam pemberian PENJASOR di universitas adalah agar dapat membina dan mengembangkan rasa kerjasama, rasa percaya diri dan rasa disiplin yang tinggi kepada setiap mahasiswa dan mahasiswinya. Berdasarkan observasi peneliti, mahasiswa yang mengikuti mata kuliah umum pendidikan jasmani dan olahraga kurang antusias, terlihat dari keikutsertaan mahasiswa dalam mengikuti pembelajarannya, namun ada juga beberapa dari mahasiswa dan mahasiswinya terlihat begitu antusias dalam mengikuti perkuliahan tersebut. 
(Suherman, 2009) mengungkapkan bahwa pembelajaran pada program pendidikan jasmani merupakan aktivitas lokomotor, mengontrol objek, kesegaran jasmani, permainan, dan keterampilan olahraga. Pengajaran pendidikan jasmani lebih mengarah pada permainan dalam olahraga, akan tetapi dalam mata kuliah umum pendidikan jasmani dan olahraga tidak akan membantu peserta didik dalam merubah bentuk fisiknya, baik secara fisik maupun anatomi karena pemberian mata kuliah umum pendidikan jasmani dan olahraga hanya diberikan satu kali dalam seminggu, sedangkan menurut beberapa ahli pembinaan olahraga dibutuhkan tiga kali dalam seminggu. Maka dari itu pendidikan jasmani dan olahraga yang hanya diberikan satu kali dalam seminggu bisa dikatakan masuk kedalam ranah kategori olahraga rekreasi.

Olahraga rekreasi merupakan aktivitas olahraga yang didalamnya terkandung unsur kesenangan ketika melakukan olahraga tersebut dan mampu memberikan penyegaran kembali rohani dan jasmani seseorang melalui olahraga rekreasi pada waktu senggang (leasure time). Namun sedikit berbeda dengan tujuan pemberian mata kuliah umum PENJASOR. Tujuan olahraga dalam pendidikan jasmani adalah untuk mendidik melalui aktivitas fisik walaupun terkadang didalam penerapannya bisa melalui olahraga rekreasi. Dengan isi pembelajaran yang menyenangkan melalui olahraga rekreasi, dapat terlihat begitu antusiasnya para mahasiswa dan mahasiswi dalam mengikuti mata kuliah pendidikan jasmani olahraga namun tidak lupa dengan lebih menekankan aktivitas jasmani peserta didik. Menurut (Graham dkk, 1993) dalam (Suherman, 2009) mengemukakan bahwa "diberikannya mata kuliah umum pendidikan jasmani dan olahraga bertujuan untuk menyediakan dan memberikan berbagai pengalam gerak untuk membentuk fondasi gerak yang kokoh pada akhirnya berdampak pada pemilihan gaya hidup yang aktif dan sehat."
Pendidikan jasmani dan olahraga merupakan suatu proses dimana bukan hanya melakukan aktivitas saja tetapi juga dalam pembelajarannya dapat berkontribusi dalam tiga domain pendidikan yaitu aspek kognitif, afektif dan psikomotor. Pemberian pembelajaran yang hanya satu kali dalam seminggu tidak akan meningkatkan kebugaran peserta didik, oleh karena itu peneliti mencoba menelusuri pada aspek affective. Aspek afektif merupakan ranah yang didalamnya berkaitan dengan nilai dan sikap. Aspek affektif dalam hal ini adalah menyangkut attitude, sikap, kepribadian dan lain-lain. Pemberian pembelajaran pendidikan jasmani dan olahraga satu kali dalam seminggu apakah dapat berpengaruh pada aspek affektif peserta didik. Menurut WHO (World Health Organization) mengemukakan, sehat mengarah pada sehat jasmani, rohani dan sosial. Melalui latihan satu kali pertemuan dalam satu minggu tidak mungkin berpengaruh terhadap jasmani. Peneliti mencoba melihat pengaruh pembelajaran mata kuliah umum pendidikan jasmani dan olahraga terhadap aspek psikis dan sosial terhadap perkembangan karakter mahasiswa di UPI.

Persoalan yang menarik bagi peneliti adalah jika pendidikan jasmani dan olahraga pada umumnya mengandung potensi pendidikan, sejauh mana olahraga itu dapat berpengaruh terhadap pembentukan watak atau karakter seseorang. Namun dalam pelaksanaannya masih banyak sekali mahasiswa dan mahasiswi yang melihat perkuliahan PENJASOR hanyalah sebatas perkuliahan yang tidak begitu banyak membutuhkan tanggung jawab dalam kepartisipasiannya maka dari itu banyak dari mereka yang masih datang telat, hanya datang dan menitipkan daftar kehadiran kepada temannya dan kurangnya perhatian terhadap mata kuliah tersebut. Melalui sistem pendidikan saat ini yang lebih menitik beratkan intelektual, membuat orang semakin lupa akan pentingnya pendidikan yang berdampak terhadap karakter ataupun perilaku mereka. Melihat pendidikan memberikan pengaruh yang cukup besar, maka 
melalui pembelajaran pendidikan jasmani dan olahraga sebagai kurikulum diperguruan tinggi, diharapkan bisa memberikan arahan tentang bagaimana menjadi manusia yang berkarakter sesuai dengan nilai-nilai pancasila. Menurut (Sartono, 2011) "Karakter yang dimaksud dalam pendidikan adalah karakter bangsa Indonesia yang sesuai dengan nilai-nilai Pancasila antara lain Beriman dan Bertakwa, Jujur dan Bersih, Santun dan Cerdas, Bertanggung jawab dan Kerja Keras, Disiplin dan Kreatif, Peduli dan Suka menolong"

Krisis karakter sekarang ini sudah memasuki ranah pada lingkungan kampus sehingga sering kali ditemui sikap dan perilaku mahasiswa yang bertentangan dengan nilai moral sehingga dibutuhkan suatu character building dalam mahasiswa. Oleh karena itu pembangunan karakter ingin mengembalikan paradigma berpikir, agar mahasiswa itu tidak hanya pintar, berpengetahuan, dan unggul tetapi juga bertanggung jawab dan beretika yang baik dan benar. Karakter merupakan watak atau tabiat perilaku setiap manusia yang bertindak secara tidak sadar karena sudah menjadi kebiasaan dan sudah tertanam dalam pikiran. Lingkungan juga sangat mempengaruhi karakter atau watak seseorang terhadap satu dengan yang lainnya. Didikan orang tua, guru serta orang lain yang memberi pengaruh kepada setiap individu haruslah memberikan contoh yang baik dan benar agar setiap individu menjadi insan yang bermutu. Menurut Musfiroh" karakter mengacu kepada serangkaian sikap (attitudes), perilaku (behaviors), motivasi (motivations), dan keterampilan (skill).

Melalui pembelajaran pendidikan jasmani diharapkan bisa membawa pesan betapa pentingnya membangun karakter dan memberikan hasil yang positif bagi setiap mahasiswa dan mahasiswi. Namun, berdasarkan observasi peneliti beberapa dari mahasiswa beranggapan mata kuliah pendidikan jasmani olahraga hanyalah sebatas perkuliahan yang berisikan aktivitas fisik yang menyenangkan, sehingga diantara mereka ada yang benar-benar mengikutinya namun ada beberapa diantara mereka juga yang tidak bersungguh sungguh dalam mengikutinya. Hal ini bisa terjadi dikarenakan kurangnya pemahaman tentang isi dari pembelajaran yang diberikan pengajar sehingga menyempitkan anggapan bahwa melalui mata kuliah umum pendidikan jasmani dan olahraga dapat membangun karakter mahasiswa dan mahasiswinya.

\section{METODE}

Metode penelitian adalah cara atau jalan yang dilakukans sebagai upaya untuk memahami dan memecahkan masalah secara ilmiah, sistematik dan logis. (Sugiyono, 2010) menjelaskan bahwa "metode penelitian pada dasarnya merupakan cara ilmiah untuk mendapatkan data dengan tujuan dan kegunaan tertentu". Dalam penelitian ini penulis menggunakan metode Deskriptif Komparatif.

Metode deskriptif dapat memecahkan serta menyelidiki masalah yang diteliti dan dapat menggambarkan keadaan yang terjadi dengan maksud untuk mendapatkan gambaran umum yang jelas, sistematis, dan akurat mengenai fakta-fakta, sifat-sifat, serta hubungan antara fenomena yang diteliti. (Arikunto, 2006) mengungkapkan bahwa "Penelitian deskriptif merupakan penelitian yang diwujudkan untuk mengumpulkan informasi mengenai suatu gejala yang ada, yaitu: keadaan gejala menurut apa adanya pada suatu penelitian yang dilakukan".

Metode penelitian deskriptif komparatif yang diterapkan dalam penelitian ini bersifat membandingkan. Jenis desain eksperimen yang digunakan adalah Intact Group Comparisson, yang dimana pada desain ini terdapat satu kelompok yang digunakan untuk penelitian, tetapi dibagi dua, yaitu setengah kelompok diberi perlakuan dan setengah kelompok lagi tidak diberi perlakuan.

Populasi penelitian merupakan suatu objek kelompok besar yang diharapkan dapat menjadi aplikasi hasil penelitian. Populasi yang digunakan dalam penelitian ini adalah 
mahasiswa dan mahasiswi yang mengikuti Mata Kuliah Umum (MKU) pendidikan jasmani dan olahraga di UPI dan mahasiswa dan mahasiswi yang belum ataupun tidak mengikuti MKU pendidikan jasmani dan olahraga. Sampel penelitian merupakan objek bagian kecil dari penelitian untuk mendapatkan informasi dari setiap orang. Sampel diambil dengan menggunakan teknik cluster random sampling. Teknik dalam pengambilan sampel pada penelitian ini menggunakan dua tahap. Tahap pertama menentukan sampel yang mengikuti mata kuliah umum pendidikan jasmani dan olahraga dan tahap yang kedua menentukan sampel yang belum mengikuti mata kuliah umum pendidikan jasmani dan olahraga. Sampel yang digunakan dalam penelitian ini adalah mahasiswa dan mahasiswi Ilmu Ekonomi Islam (IEKI)-UPI angkatan 2015 kelas A yang mengikuti perkuliahan MKU PENJASOR dan mahasiswa/i yang belum mengikuti mata kuliah umum penjas dan olahraga sebagai pembandingnya.

Dalam penelitian dibutuhkan instrument untuk mengetahui alat ukur apa yang digunakan peneliti untuk mendapatkan data dari sampel penelitian. Instrument penelitian merupakan alat bantu peneliti untuk mendapatkan informasi secara kuantitatif dan dapat pula membantu peneliti dalam mengumpulkan data agar mempermudah penelitian. Dalam penelitian ini, instrument penelitian yang digunakan berupa angket skala likert. Suatu skala untuk menilai sikap seseorang terhadap suatu topic. Angket atau kuesionare merupakan seperangkat pernyataan ataupun pertanyaan secara tertulis

Dalam penelitian ini menggunakan metode penelitian deskriptif komparatif dan teknik pengumpulan datanya menggunakan angket atau kuesioner mengenai kepercayaan (trustworthinees), tanggung jawab (responsibillity), rasa hormat (respect), rasa adil (fairness), peduli (caring) dan sosial (citizenship). Angket yang digunakan peneliti adalah angket tertutup dimana responden hanya memberikan jawaban yang disesuaikan dengan pernyataan/pertanyaan yang telah disediakan peneliti. Skala likert yang diberikan peneliti berupa pernyataan-pernyataan yang diberikan kepada responden dengan lima alternative jawaban misalnya: SS, S, TT, TS, STS agar peneliti dapat lebih mudah mengetahui jawaban yang diisi responden bersungguh-sungguh ataukah asal-asalan.

Untuk memperoleh data yang relevan dan akurat diperlukan alat pengumpul data yaitu alat ukur yang valid dan reliabel. Salah satu yang diperlukan dengan jalan uji coba (try out). Dari uji coba tersebut diharapkan dapat diketahui validitas dan realibilitas instrument tersebut. Uji coba angket dilakukan pada 18 Desember 2016 bertempat di Universitas Pendidikan Indonesia yang diberikan kepada mahasiswa dan mahasiswi Pendidikan Ekonomi sebanyak 29 orang yang mengikuti mata kuliah umum pendidikan jasmani dan olahraga, selanjutnya dicari validitas dan reabilitasnya setelah itu pernyataan yang valid diberikan kepada mahasiswa dan mahasiswi yang belum mengikuti perkuliahan pendidikan jasmani olahraga sebagai pembandingnya. Sebelum uji coba, maka peneliti melakukan tahapan pengkonstruksian angket.

Dari 52 butiran pernyataan yang peneliti buat, terdapat 33 pernyataan yang valid. Dikatakan valid jika nilai dikolom Corrected item-total correlation mendekati ataupun melebihi patokan 0,2. Dikatakan tidak valid jika terdapat angka minus (-) ataupun kurang dari 0,2. Berdasarkan hasil uji didapat beberapa butiran pernyataan yang dikatakan tidak valid yaitu berjumlah 19 butir. Butiran yang dinyatakan tidak valid dibuang, dikarenakan butiran yang valid sudah mewakili setiap subkomponen.

\section{HASIL DAN PEMBAHASAN}

Seperti yang sudah dijelaskan sebelumnya dalam bab tiga, sebuah data dikatakan normal apabila nilai sig. (p) $>0,05$ dan data dinyatakan tidak normal apabila nilai sig. (p) $<0,05$. Dapat dilihat pada output diatas bahwa nilai sig. (p) yang mengikuti mata kuliah umum penjasor 
sebesar 0.200 dan yang tidak mengikuti perkuliahan penjasor sebesar 0.200. Data kelompok sampel yang mengikuti mku penjasor Sig. $\mathrm{p}=0.200>0.05$ data berdistribusi normal. Data kelompok sampel yang tidak mengikuti mku penjasor Sig. $\mathrm{p}=$ $0.200>0.05$ data berdistribusi normal. Dapat dilihat kedua data diatas memiliki taraf sig. > 0.05 maka kedua data diatas dapat dikategorikan data berdistribusi normal dan bisa dilanjutkan untuk menguji homogenitas dan menguji apakah terdapat perbedaan karakter mahasiswa yang mengikuti dan tidak mengikuti mata kuliah umum penjasor.

Dapat dilihat pada tabel 4.3 bahwa pada kolom Lavenes Test sig. ( $p)=0,004$ dimana $p$ $=0,004<0,05$ maka data dinyatakan tidak homogen. Sebuah data dikatakan homogen apabila nilai taraf sig. $>0.05$ dan dikatakan tidak homogen apabila nilai sig. $<0.05$ Ketika data tidak homogen maka selanjutnya peneliti menggunakan asumsi bahwa varian tidak sama (Equal Variance Not Assume). Maka dapat dituliskan sebagai berikut, $\mathrm{t}$ dengan equal variance not assume $=7.777$ dan signifikansi $=$ 0,000 maka dapat diartikan $\mathrm{p}=7,777$ sig. $=$ $0,000<0,05$ maka Ho ditolak, jika Ho ditolak maka $\mathrm{H} 1$ yang masuk dan dapat disimpulkan terdapat perbedaan karakter mahasiswa yang mengikuti dan yang tidak mengikuti mata kuliah umum pendidikan jasmani dan olahraga.

Peneliti mengambil dua data yang berbeda, diantaranya yang mengikuti mata kuliah umum pendidikan jasmani olahraga dan yang tidak mengikuti mata kuliah umum pendidikan jasmani olahraga. Peneliti memberikannya melalui angket/kuesionare dimana kuesionare tersebut terdapat pernyataan-pernyataan dan altenative jawaban. Dalam pemberian kuesioanre, peneliti terfokus kedalam enam pilar karakter yang sebelumnya telah dibahas sebagai tolok ukur untuk melihat karakter seseorang. Diantaranya kepercayaan (trustworthinees), tanggung jawab (responsibillity), rasa hormat (respect), rasa adil (fairness), peduli (caring) dan sosial (citizenship). Dalam penelitian kali ini peneliti mengambil dua data, yaitu mahasiswa dan mahasiswi yang mengikuti mata kuliah umum pendidikan jasmani olahraga dan yang tidak mengikuti mata kuliah umum pendidikan jasmani olahraga. Kuesionare diberikan agar peneliti dapat melihat perbandingan karakter mahasiswa dan mahasiswi yang mengikuti maupun yang tidak mengikuti mata kuliah umum pendidikan jasmani olahraga. Data tersebut lalu diolah dan dilihat uji kenormalitasannya ketika sudah terlihat, selanjutnya data dicari homogenitasnya seperti yang sudah dijelaskan sebelumnya.

Dengan keikutsertaan mahasiswa dan mahasiswi dalam pembelajaran penjasor mengharuskan mereka lebih banyak beraktivitas dan bergerak serta berkomunikasi dengan dosen, pengajar ataupun dengan teman sekelas atau dengan jurusan lain. Sesuai dengan ungkapan (Mahendra, 2009) yang mengemukakan bahwa " pendidikan jasmani pada hakikatnya adalah proses pendidikan yang memanfaatkan aktivitas fisik untuk menghasilkan perubahan holistik dalam kualitas individu, baik dalam hal fisik, mental, serta emosional" perubahan yang bersifat holisitk merupakan perubahan dalam diri secara menyeluruh tidak terbagi bagi antara jiwa dan raganya. Hal ini juga yang memang dirasakan mahasiswa dan mahasiswi yang mengikuti perkuliahan pendidikan jasmani olahraga sehingga banyak dari mereka menjawab angket dengan skor yang tinggi. Keikutsertaan mahasiswa dan mahasiswi dalam mata kuliah umum pendidikan jasmani olahraga bisa jadi ladang untuk mereka mengembangkan kepribadian agar lebih baik.

\section{KESIMPULAN}

Berdasarkan hasil pengolahan data dan analisis data menyatakan bahwa setiap mahasiswa yang mengikuti mata kuliah umum pendidikan jasmani olahraga dan mahasiswa yang tidak mengikuti mata kuliah umum pendidikan jasmani olahraga terdapat perbedaan dalam karakternya. Penelitian ini diperkuat berdasarkan uji Independent Sample t-test. 
Seperti yang sudah dijelaskan pada bab IV, ketika data dinyatakan tidak homogen maka menggunakan equal variance not assumed. Pada tabel equal variance not assumed tertulis bahwa nilai $\mathrm{p}=7,777$ dan sig. $=0,000<0,05$ ketika nilai sig lebih kecil dari 0,05 maka hipotesis yang diterima adalah H1. Maka dapat ditarik kesimpulan bahwa terdapat perbedaan karakter mahasiswa yang mengikuti dan yang tidak mengikuti mata kuliah umum pendidikan jasmani olahraga.

\section{DAFTAR PUSTAKA}

Arikunto, S. (2006). Prosedur Penelitian Suatu Pendekatan Praktik. Bandung: Rineka Jaya

Mahendra , A. (2009). Azas dan Falsafah Pendidikan Jasmani. Bandung : Prodi PJKR FPOK UPI Bandung.

Sartono. (2011). Pengintegrasian Pendidikan Karakter dalam Pengembangan Kurikulum Tingkat Satuan Pendidikan. Makalah Disertasi

Sugiyono. (2010). Metode PenelitianPendidikan (PendekatanKuantitatif, Kualitatif, dan $R \& D)$ Bandung :Alfabeta

Suherman, A. (2009). Revitalitas Pengajaran Pendidikan Jasmani. Bandung: Bintang WarliArtika

Suherman, A dan Rahayu, N I (2016). Modul Statistika untuk Ilmu Keolahragaan. Bandung : Universitas Pendidikan Indonesia. 